\title{
PENGARUH CORPORATE BRAND TERHADAP CONSUMER LOYALTY PADA SHOWROOM HYUNDAI PONDOK INDAH JAKARTA SELATAN
}

\author{
Anah Furyanah \\ Email : anahfuryanah@yahoo.co.id
}

\begin{abstract}
ABSTRAK
Tujuan dari penelitian ini adalah untuk mengetahui pengaruh functional benefit dan Symbolic benefit terhadap attitudinal dan behavioral consumer loyalty. Penelitian empiris ini menggambarkan adanya hubungan yang signifikan diantara functional benefit, emotional benefit dan symbolic benefit dan consumer attitudinal dan behavior loyalty. Penelitian ini dilakukan pada 92 pelanggan di showroom Hyundai Pondok Indah. Cronbach alpha dan analisis regresi yang digunakan dalam penelitian ini dengan menggunakan SPSS versi 12.00 adalah sebagai alat yang mendukung dalam validasi construct pemahaman teori argumentasi sebagai dasar dalam pengukuran hasil. Kesimpulan dalam penelitian ini adalah functional benefit, emotional benefit, dan symbolic benefit berpengarus positif terhadap attitudinal loyalty dan behavior customer loyalty.
\end{abstract}

Kata kunci : Functional Benefit, Emotional Benefit, Symbolic Benefit, Attitudinal Customer Loyalty, Behavioral Customer Loyalty

\begin{abstract}
The purpose of this research is to investigate the influence of the functional benefit, emotional benefit and symbolic benefit on attitudinal and behavioural consumer loyalty. This resaerch empirically demonstrates a significant relationship between functional benefit, emotional benefit and symbolic benefit and consumer attitudinal and behavioural loyalty. The research is based on a sample of 92 consumers of an automobile Hyunday in showroom Pondok Indah - South of Jakarta. Cronbach alpha and Regression analysis were used to establish in this research with SPSS version 12.00 as a supporting tools where the construct validity covers the understanding of theoretical argumentation as a basic of the measurement results. Conclusion of this research is the functional, emotional and symbolic benefit contribute a positive effect to attitudinal and behavioral customer loyalty.
\end{abstract}

Key word : Functional Benefit, Emotional Benefit, Symbolic Benefit, Attitudinal Customer Loyalty, Behavioral Customer Loyalty 
A. Pendahuluan

Dengan beragamnya produk yang dikembangkan oleh perusahaan memberikan pilihan strategi bagi pihak marketing untuk menarik pelanggan agar dapat memilih produk yang ditawarkan. Hal tersebut menjadikan pihak marketing harus berusaha untuk membuat strategi baru untuk dapat meningkatkan nilai tambah (added value) yang dibutuhkan oleh perusahaan (Anisimova, 2007).

Untuk menjaga hubungan dengan konsumen dalam meningkatkan produktivitas penjualan tersebut adalah dengan mengadopsi corporate branding strategy dari perusahaan itu sendiri. Corporate branding akan memberikan keuntungan bagi perusahaan untuk meningkatkan dan mendukung perbedaan produk suatu barang yang diproduksi oleh suatu perusahaan untuk membedakan karakterstik dari suatu produk, dimana saat ini konsumen sangat pintar dan jeli untuk membedakan produk yang akan dibelinya (Tickle et.al, 2003).

Faktor yang mempengaruhi permintaan konsumen dalam industri otomotif menurut IBIS World (2005) diantaranya adalah harga kendaraan itu sendiri, tarif, pendapatan dan inovasi-inovasi yang ada untuk kondisi kendaraan itu sendiri serta faktor demografi konsumen. Hal ini perlu untuk meningkatkan brand communication untuk meningkatkan kembali daya beli konsumen. Salah satu cara untuk bersaing dalam memenangkan persaingan dan meningkatkan kesamaan produk antara lain dengan mengadopsi adanya corporate branding strategy.

Untuk barang-barang yang termasuk dalam kategori barang-barang mewah atau complex seperti mobil, konsumen dalam melakukan pembelian selalu menggunakan berbagai perhitungan untuk selanjutnya memutuskan untuk membeli (Bruck et.al, 2000), pengujian multi dimensi dari pengalaman pemakai dalam menggunakan produk tersebut telah dianggap paling tepat untuk kemudian memutuskan untuk membeli. Pada saat kegunaan produk atau functional produk digunakan akan melibatkan consumer performance, safety dan quality attribute, emotional serta symbolic brand yang akan menjadi nilai sebagai alat perhitungan konsumen untuk sebuah variasi. Sehingga pada akhirnya menunjukkan kepada konsumen dalam menggunakan nama merek untuk mengevaluasi dalam memesan suatu produk dengan merek bergengsi (Brucks et., al, 2000). Sehingga dapat disimpulkan bahwa faktor dari customer benefit dapat dilihat dari functional benefit, emotional benefit dan symbolic benefit dalam memutuskan pembelian suatu produk sebagai loyalitas konsumen secara attitudinal dan behavioral.

Menurut Sweeney dan Soutar (2001) dalam penelitiannya menerapkan bahwa consumer value construct merupakan kombinasi dari functional benefit, emotional benefit dan social benefit yang ditemukan 
melalui pengukuran keseluruhan nilai-nilai untuk pilihan konsumen yang lebih baik daripada pengukur dengan single attributes.

Penelitian ini akan sama dengan penelitian sebelumnya yang ditujukan kepada pengguna otomotive hanya saja dalam penelitian ini lebih ditekankan pada merek mobil Hyundai. Pebedaan dari penelitian sebelumnya yang dilakukan oleh Anisimova (2007) terletak pada beberapa variable yang tidak dimasukan dalam penelitian ini. Adapun variable yang tidak dimasukkan dalam penelitian ini antara lain corporate activities, corporate association dan corporate values. Sedangkan dalam penelitian ini variable yang dimasukkan antara lain variable yang berhubungan dengan consumer benefit yaitu functional benefit, emotional benefit, dan symbolic benefit. Sedangkan variabel yang dilihat dari segi loyalitas pelanggannya adalah attitudinal dan behavioral consumer loyalty.Berdasarkan pada latar belakang diatas, penelitian ini bertujuan memahami pengaruh functional benefit, emotional benefit dan symbolic benefit terhadap attitudinal dan behavioral consumer loyalty pada penjualan mobil merek Hyundai di showroom Pondok Indah - Jakarta Selatan.

\section{B. Perumusan Masalah}

(1) Apakah terdapat pengaruh functional benefit terhadap attitudinal consumer loyalty?, (2) Apakah terdapat pengaruh emotional benefit terhadap attitudinal consumer loyalty?, (3) Apakah terdapat pengaruh symbolic benefit terhadap attitudinal consumer loyalty?, (4) Apakah terdapat pengaruh functional benefit terhadap behavioral consumer loyalty?,(5) Apakah terdapat pengaruh emotional benefit terhadap behavioral consumer loyalty?, (6) Apakah terdapat pengaruh symbolic benefit terhadap attitudinal consumer loyalty?

\section{Tujuan Penelitian}

Berdasarkan perumusan masalah diatas maka tujuan penelitian ini adalah : (1) Untuk mengetahui apakah terdapat pengaruh functional benefit terhadap attitudinal consumer loyalty?, (2) Untuk mengetahui apakah terdapat pengaruh emotional benefit terhadap attitudinal consumer loyalty?, (3) Untuk mengetahui apakah terdapat pengaruh symbolic benefit terhadap attitudinal consumer loyalty?, (4) Untuk mengetahui apakah terdapat pengaruh functional benefit terhadap behavioral consumer loyalty?, (5) Untuk mengetahui apakah terdapat pengaruh emotional benefit terhadap behavioral consumer loyalty?, (6) Untuk mengetahui apakah terdapat pengaruh symbolic benefit terhadap behavioral attitudinal consumer loyalty?

\section{Landasan Teori}

Sebuah produk memiliki dua keuntungan yaitu functional benefit/functional attribut dan emotional benefit. Functional attribut/benefit adalah manfaat yang diberikan oleh sebuah produk berdasarkan fungsi yang 
diberikan oleh produk tersebut melalui fitur-fitur yang diberikan. Produk akan memberikan keuntungan dengan baik dan benar melalui functional attribut/benefit pada mereknya (Putri, 2007).

Menurut Kotler dan Amstrong (2008), perbedaan emosional lebih ditekankan pada mencampuradukan perasaan negatif dan positif yang dapat mendorong pada keinginan untuk membeli. Hal ini termasuk didalamnya adalah rasa takut, penyesalan, rasa malu untuk dapat bertukar pikiran dengan orang lain dalam berbagai hal dan mereka menyerukan perbedaan emosional positif melalui sikap seperti mencintai, humor, rasa bangga dan senang.

symbolic benefit merupakan keuntungan yang didapat melalui tanda atau logo atau simbol yang ada pada merek yang berdampak pada penggunaan suatu merek, dimana dapat dikatakan bahwa merek tersebut digunakan oleh konsumen untuk disampaikan kepada konsumen lainnya tentang keuntungan dengan menggunakan merek tersebut. Dampak dari tanda atau simbol suatu merek dapat menjadi dasar terhadap image secara umum atau jenis konsumen yang menggunakan merek tersebut. Ketika menggunakan suatu merek, konsumen menjadi salah satu anggota yang tergabung dalam merek tersebut (Aaker, 1997) dalam Hilgesson (2004).

Loyalitas dapat diartikan sebagai suatu komitmen yang mendalam untuk melakukan pembelian ulang produk atau jasa yang menjadi preferensinya secara konsisten pada masa yang akan datang dengan cara membeli ulang merek yang sama meskipun ada pengaruh situasional dan usaha pemasaran yang dapat menimbulkan perilaku peralihan (Riana, 2008).

Biaya yang rendah terhadap pelayanan servis kepada konsumen, penurunan biaya kepada pelanggan secara sensitif, dan adanya word of mouth dari konsumen yang satu ke konsumen yang lainnya merupakan nilai point bagi perusahaan dalam membangun consumer loyalty. Secara umum, consumer loyalty telah didefinisikan melalui berbagai bentuk penjelasan yang meliputi aspek purchase behavioral (Ehrenberg, 1988 dan DuWors dan Haines, 1990) dalam Anisimova, 2007).

Menurut Day dan Jacoby (1971) dalam Shiang - Ko (2009) bahwa konsep attitudinal consumer loyalty merupakan keadaan dimana konsumen menerapkan pembelian kembali merek tersebut yang dipakainya yang didasari oleh sikap kognitif, afektif dan evaluative serta aspek kecenderungan untuk memilih merek setelah merek digunakan atau dipakai.

Behavioural consumer loyalty pada dasarnya merupakan perwakilan atau representasi dari aturan perilaku yang diekspresikan secara lebih oleh konsumen setelah menggunakan merek tersebut. Pengukuran behavioral consumer loyalty merupakan operasionalisasi yang berdasarkan pada attitudinal consumer loyalty, tetapi dimodifikasi untuk melukiskan secara 
nyata pembelian kembali dan merekomendasikan smelalui perilaku secara intensif (Musa, 2005).

Berdasarkan latar belakang, rumusan masalah, kajian teori, dan penelitian sebelumnya maka dirumuskan hipotesis sebagai berikut :

1. HI : Terdapat pengaruh functional benefit terhadap attitudinal consumer loyalty.

2. $\mathrm{H} 2$ : Terdapat pengaruh emotional benefit terhadap attitudinal consumer loyalty.

3. H3 : Terdapat pengaruh symbolic benefit terhadap attitudinal consumer loyalty.

4. H4 : Terdapat pengaruh functional benefit terhadap behavioural consumer loyalty.

5. H5 : Terdapat pengaruh emotional benefit terhadap behavioural consumer loyalty.

6. H6 : Terdapat pengaruh symbolic benefit terhadap behavioural consumer loyalty.

Gambar 1 : kerangka konseptual

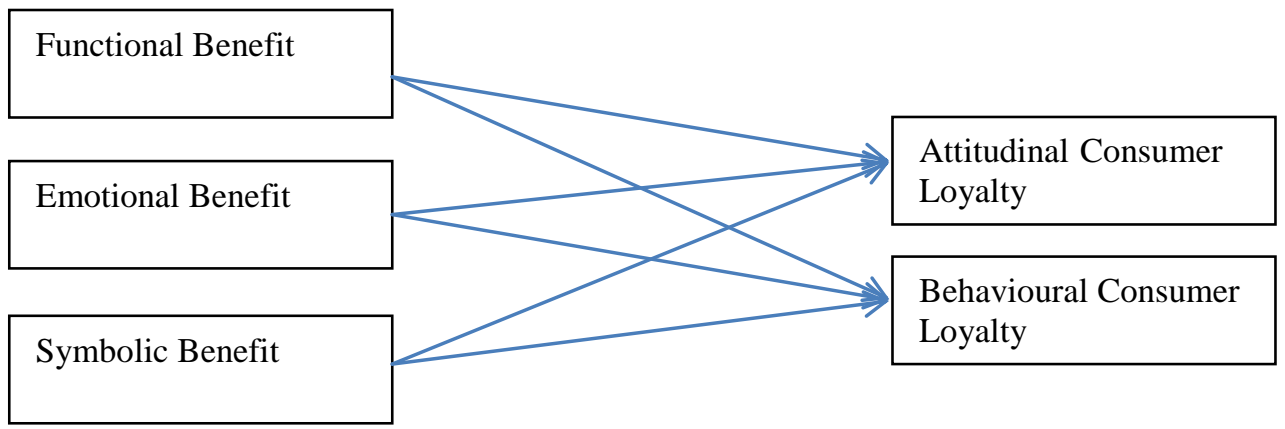

\section{E. Metodologi}

Penelitian ini mengacu pada penelitian yang telah dilakukan oleh Anisimova (2007). Metode penelitian yang digunakan adalah penelitian analisis hipotesis yang merupakan metode penelitian yang menjelaskan fenomena dalam bentuk hubungan atau pengaruh satu variabel dengan variabel lainnya.

\section{Functional benefit}

Diadopsi dari penelitian yang dilakukan oleh Anisimova (2007) terdiri dari 6 pernyataan antara lain :

1. Mutu yang konsisten (Consistent Quality)

Dengan menggunakan mobil Hyundai saya mendapatkan kualitas mutu yang konsisten dari mobil tersebut.

2. Mempunyai nilai jual (value of money) 
Dengan menggunakan mobil merek Hyundai saya mendapatkan nilai jual yang lebih dari merek mobil lainnya.

3. Hemat Bahan Bakar (fuel efficiency)

Dengan menggunakan mobil merek Hyundai akan lebih menghemat bahan bakar.

1. Mempunyai nilai estetika

Dengan menggunakan mobil merek Hyundai saya menrasakan nilai estetika lebih dari merek mobil lainnya.

2. Ciri Khas Pribadi (Individual)

Mobil merek Hyundai saya merasakan mempunyai cirri khas pribadi tersendiri jika dibanding dengan merek lainnya.

3. Praktis (Practically)

Dengan menggunakan mobil merek Hyundai saya merasa praktis.

Emotional benefit

Diadopsi dari penelitian yang dilakukan oleh Anisimova (2007) terdiri dari 5 pernyataan antara lain :

1. Kesenangan Pribadi (Driving Pleasure)

Dengan mengendarai mobil merek Hyundai, saya merasakan kesenangan pribadi.

2. Merasakan Ketenangan (a feeling of serenity)

Dengan mengendarai mobil merek Hyundai, saya merasakan ketenangan di dalam mobil.

3. Berjiwa Muda (youthful spirit)

Dengan menggunakan mobil merek Hyundai saya merasa berjiwa muda/seperti eksekutif muda.

4. Merasakan petualangan (a feeling adventure)

Dengan menggunakan mobil merek Hyundai saya merasakan petualangan. Merasakan menyatu/sehati dengan mobil (a sense of oneness with the car) Dengan menggunakan mobil merek Hyundai saya serasa menyatu dengan mobil tersebut.

\section{Symbolic benefit}

Diadopsi dari penelitian yang dilakukan oleh Anisimova (2007) terdiri dari 7 pernyataan antara lain :

1. Pilihan yang cerdas (Feel that you made a smart choice)

Dengan menggunakan mobil merek Hyundai merupakan pilihan yang cerdas.

Unggul dari yang lain (lebih menonjol) (stand out in crowd)

Mobil merek Hyundai merupkan mobil yang unggul disbanding dengan mobil merek lainnya.

Meningkatkan image pribadi (enhance your personal image) 
Dengan menggunakan mobil merek Hyundai meningkatkan image pribadi.

2. Menaikan tingkatan sosial (Get social approval)

Dengan menggunakan mobil merek Hyundai, menandakan tingkatan status sosial secara langsung.

Kepribadian yang meningkat (Express your personality)

Attitudinal Consumer Loyalty

Diadopsi dari penelitian yang dilakukan oleh Bennet dan Thiele (2002) terdiri dari 5 pernyataan antara lain :

1. Pembelian kembali (Repeat purchase)

Dengan pelayanan yang diberikan oleh Hyundai saya berkeinginan suatu saat akan kembali membeli merek Hyundai untuk merek mobil berikutnya.

2. Pilihan (Preference)

Mobil merek Hyundai merupakan mobil merek pilihan saya.

3. Komitmen (Commitment)

Saya mempunyai komitment untuk tetap memilih mobil merek Hyundai sebagai mobil pribadi saya.

4. Mengingat/Ingatan (Consumer Retention)

Ketika mendengar merek Hyundai mengingatkan akan mobil saya.

5. Allegiance

Saya akan setia dengan mobil saya merek Hyundai

\section{Behavioural Consumer Loyalty}

Diadopsi dari penelitian yang dilakukan oleh Sirohi et.al (1998) yang terdiri dari

3 pernyataan antara lain :

1. Kemungkinan untuk melanjutkan berbelanja barang lainnya (Likelihood to continue shopping)

2. Saya merasa akan terus mempergunakan showroom ini untuk pembelian barang-barang lainnya sesudah mempunyai mobil Hyundai sebagai mobil probadi saya.

3. Kemungkinan untuk menggunakan empat/showroom ini untuk keperluan lainnya untuk masa yang akan datang (likelihood to use the showroom for more you grocery needs in the next time).

4. Saya akan terus mempergunakan showroom ini untuk keperluan lainnya untuk memenuhi kebutuhan mobil Hyundai saya.

5. Kemungkinan untuk merekomendasikan tempat/showroom ini ke temanteman atau rekan-rekan lainnya (likelihood to recommend showroom to a friend).

6. Saya akan merekomendasikanpenggunaan mobil saya akan merekomendasikan showroom yang saya gunakan kepada teman-teman saya. 
Metode penarikan sample yang digunakan pada penelitian ini adalah purposive sampling yaitu penarikan sample berdasarkan pertimbangan dimana sample yang dipilih didasarkan pada kriteria tertentu (Hermawan, 2006). Produk yang digunakan sebagai objek penelitian pada penelitian ini adalah otomotive khususnya mobil merek Hyundai yang ada di showroom Pondok Indah, Jakarta Selatan. Sampel yang dipilih adalah mereka yang telah membeli produk mobil merek Hyundai dan sedang melakukan service di bengkel showroom Pondok Indah - Jakarta Selatan.

penelitian sebelumnya yang dilakukan oleh Anisimova (2007). Metode penelitian yang digunakan adalah hypothesis analysis yang bertujuan untuk melihat sejauh mana pengaruh setiap variable mempengaruhi variabel lainnya.

Penentuan jumlah sample sebanyak 200 responden dimana berdasarkan Hair, et.al (2006) menganjurkan penarikan sampel dengan maximum likehood estimation (MLS) adalah sebanyak100 - 200 responden dengan alpha sebesar 5\% untuk mendapatkan kemampuan menjelaskan (power level) sebesar $90-90 \%$.

Penelitian ini menggunakan data primer dimana data dikumpulkan dengan menggunakan teknik kuisioner, yaitu dengan memberikan pertanyaan tertulis yang disebarkan secara langsung bagi pelanggan yang melakukan service mobil di Showroom Pondok Indah maupun pengisian dengan menggunakan telepon kepada responden karena adanya kesibukan dari pelanggan. Sebelum di sebar, kuisioner diuji terlebih dahulu dengan menggunakan :

1. Uji Realibilitas

2. Uji Validitas

Metode analisis data yang digunakan dalam penelitian ini adalah dengan menggali bahan yang ada dengan menggunakan regresi berganda atau multiple regression dengan dikembangkan dari model-model pengukuran yang ada dari kelima variabel.Tujuan analisis regresi secara umum adalah untuk menentukan persamaan garis regresi berdasarkan nilai konstanta dan koefisien regresi yang dihasilkan, disamping itu untuk mencari korelasi secara bersama-sama antara variabel bebas dengan variabel terikat serta menguji signifikansi pengaruh variabel bebas terhadap variabel terikat melalui uji $\mathrm{F}$

\section{F. Hasil dan Pembahasan}

Berikut ini statsitik deskriptif untuk setiap variabel dalam penelitian ini secara keseluruhan yang ditunjukkan dalam tabel. 
Tabel 1 : Statistik Deskriptif

\begin{tabular}{cccccc}
\hline Variable & N & Min & Max & Mean & Std. Deviasi \\
\hline Functional Benefit & 92 & 2,859 & 3,848 & 3,556 & $3 ; 061$ \\
Emotional Benefit & 92 & 3,391 & 3,902 & 3,750 & 2,712 \\
Emotional Benefit & 92 & 3,087 & 3,674 & 3,357 & 3,109 \\
Attitudinal Loyalty & 92 & 3,533 & 4,065 & 3,763 & 3,141 \\
Behavioral Loyalty & 92 & 3,739 & 4,087 & 3,866 & 1,697 \\
\hline
\end{tabular}

ValidN (Listwise)

Berdasarkan table 1 dapat dilihat bahwa indikator penilaian variabel functional benefit memiliki nilai rata-rata atau mean sebesar 3,556 dengan nilai minimum 2,859 dan nilai maksimum 3,848 . Hal ini menyatakan bahwa jika nilai mean 3,556 yang artinya bahwa responden rata-rata menilai mobil merek Hyundai memberikan mutu yang konsisten dan niobil merek Hyundai merupakan mobil yang mempunyai kualitas yang bagus. Dengan menggunakan mobil merek Hyundai responden mendapatkan nilai jual yang lebih dari mobil merek lainnya.

Disamping itu dengan menggunakan mobil merek Hyundai responden merasakan cukup menghemat bahan bakar, dan dengan menggunakan merek Hyundai responden cukup merasakan nilai estetika yang lebih ketika menggunakan mobil-mobil merek lainnya. Responden pun menilai bahwa dengan menggunakan mobil merek Hyundai cukup merasa mempunyai ciri khas tersendiri jika dibanding dengan menggunakan merek lainnya. Dan yang terpenting menurut responden dengan menggunakan mobil merek Hyundai responden merasa cukup praktis dalam kegiatan sehari-hari. Pada pengujian ini dimensi-dimensi yang ada dalam variable ini mempunyai standar deviasi sebesar 3,061.

Indikator pengukuran mengenai variabel emotional benefit memiliki rata-rata atau nilai mean sebesar 3,750 dengan nilai minimum 3,391 dan nilai maksimum 3,902 Jika nilai mean sebesar 3,750 berarti responden merasakan kessenangan pribadi, disamping itu responden dengan menggunakan mobil merek Hyundai merasakan ketenangan ketika berada di mbil tersebut. Responden juga cukup merasakan youthfull spirit ketika menggunakan mobil merek Hyundai atau merasa seperti eksekutif muda ketika menggunakan mobil merek Hyundai tersebut. Selain itu ketika menggunakan mobil merek Hyundai responden cukup merasakan seperti melakukan petualangan ketika menggunakan mobil tersebut.

Dan disamping itu dengan menggunakan mobil merek Hyundai responden merasa menyatu dengan mobil tersebut. Pada pengukuran variable 
ini dimensi-dimensi yang ada dalam variabel ini mempunyai standar penyimpangan atau staridar deviasi sebesar 0,9780. Sedangkan pengukuran pada indikator variable symbolic benefit dapat diketahui rata-rata atau nilai mean sebesar 3,357 dengan nilai minimum 3,087 dan nilai maksimum 3,674. Jika nilai mean sebesar 3,357 yang menaridakan responden secara keseluruhan menunjukkan bahwa dengan menggunakan mobil merek Hyundai merupakan salah satu pilihan yang cukup cerdas, dan responden menganggap bahwa dengan menggunakan mobil merek Hyundai responden merasakan keunggulannya dan kenyamanannya disaat mengendarainya.

Responden merasakan dengan menggunakan mobil merek Hyundai terdapat tingkatan status sosial secara langsung ${ }^{\wedge}$ disamping itu dengan menggunakan mobil merek Hyundai beraiti responden merasakan kepribadian yang meningkat. Dari hasil pengukuran pada indikator ini dimensi-dimensi yang ada dalam variabel ini mempunyai standar penyimpangan atau standar deviasi sebesar 3,109.

Selanjutnya untuk pengukuran variable attitudinal customer loyalty dapat diketahui bahwa rata-rata atau nilai mean sebesar 3,763 dengan nilai minimum 3,533 dan nilai maksimum 4,065. Jika nilai mean sebesar 3,763 menandakan bahwa dengan pelayanan yang diberikan oleh mobil merek Hyundai responden merasa puas, sehingga akan kembali lagi untuk membeli mobil merek Hyundai berikutnya. Disamping itu mobil merek Hyundai menurut responden adalah memang merek mobil pilihan yang didambakan oleh setiap responden.

Berdasarkan hal ini juga responden merasa berkomitment untuk tetap memilih mobil merek Hyundai sebagai mobil pribadi para responden. Untuk itu responden merasa ketika mendengar mobil merek Hyundai mengingatkan akan mobil yang dipakainya. Sehingga responden merasa akan setia dengan mobil Hyundai tersebut. Dari hasil pengukuran pada indikator ini dimensidimensi yang ada dalam variabel ini mempunyai standar penyimpangan atau standar deviasi sebesar 3,141

Selanjutnya untuk pengukuran variable behavioral customer loyalty dapat diketahui bahwa rata-rata atau nilai mean sebesar 3,866 dengan nilai minimum 3.739 dan nilai maksimum 4,087. Jika nilai mean sebesar 3,866 menandakan bahwa responden akan terus mempergunakan showroom tersebut, sebagai pembelian barang-barang lainnya atau service lainnya sebagai pengguna mobil merek Hyundai.

Disamping itu dengan menggunakan mobil merek Hyundai responden akan terus menggunakan showroom tersebut untuk keperluan lainnya sesuai dengan kebutuhan mobil responden. Serta dengan menggunakan mobil merek Hyundai berdasarkan pelayanan yang diberikan responden akan merekomendasikan showroom tersebut ke konsumen lainnya sesama pengguna mobil Hyundai. Dari hasil pengukuran pada indikator ini dimensi- 
dimensi yang ada dalam variabel ini mempunyai standar penyimpangan atau standar deviasi sebesar 1,697.

\section{Analisa Hasil dan Pembahasan}

Berikut ini merupakan hasil uji hipotesis-hipotesis yang telah dilakukan :

Tabel 2 : Hasil Pengujian Hipotesis

\begin{tabular}{|c|c|c|c|c|c|c|}
\hline Hipotesis & & $R^{2}$ & & $T$ & $F$ & Sig \\
\hline $\mathrm{H} 1$ & $\begin{array}{l}\text { Functional Benefit } \\
\text { Attitudinal Loyalty }\end{array}$ & 0,473 & 0,688 & 8.988 & 80.781 & 0.000 \\
\hline $\mathrm{H} 2$ & $\begin{array}{l}\text { Emotional Loyalty } \\
\text { Attitudinal Loya Ity }\end{array}$ & $\overline{0,335}$ & 0,579 & 6.735 & 45.365 & 0.000 \\
\hline H3 & $\begin{array}{l}\text { Symbolic Benefit } \\
\text { Attitudinal Loyalty }\end{array}$ & 0,348 & 0,590 & 6,932 & 48.042 & 0.000 \\
\hline $\mathrm{H} 4$ & $\begin{array}{l}\text { Functional Benefit } \\
\text { Behavioral Loyalty }\end{array}$ & 0,257 & 0,507 & 5.574 & 31.067 & 0.000 \\
\hline H5 & $\begin{array}{l}\text { Emotional Benefit } \\
\text { Behavioral Loyalty }\end{array}$ & 0,119 & 0,346 & 3.0494 & 12.208 & 0.000 \\
\hline $\mathrm{H} 6$ & $\begin{array}{l}\text { Symbolic Benefit } \\
\text { Behavioral Loyalty }\end{array}$ & 0,316 & 0,562 & 6.449 & 41.592 & 0.000 \\
\hline
\end{tabular}

S.E $=$ Standar Error

Signifikansi pada kondisi $p<0.05$

Dalam penelitian ini diajukan tiga hipotesis dan berikut ini hasil uji hipotesisnya adalah sebagai berikut:

\section{Hipotesis \# 1}

Hipotesis pertama menguji pengaruh functional benefit terhadap attitudinal customer loyalty. Hipotesis nol $(\mathrm{Ho})$ dan hipotesis alternatifnya (Ha) disusun sebagai berikut:

Ho1 : Tidak terdapat pengaruh ,positif antarafuntional benefit terhadap attitudinal customer loyalty

Hal : Terdapat pengaruh positif antarafunctional benefit terhadap attitudinal customer loyalty.

Pada tabel diatas dapat dilihat bahwa hasil pengujian regresi linier untuk variable functional benefit sebagai variabel bebas terhadap attitudinal customer loyalty sebagai .variabel terikat. F-test sebagai pengujian secara keseluruhan pada persamaan regresi yang akan diuji, menunjukkan angka sebesar 80,782 dengan mempertimbangkan angka signifikansi dibawah $p$ ( $p$ $=0,000$ atau $p<0.05$ ) maka Ho ditolak sehingga didapat hasil bahwa persamaan regresi ini secara keseluruhan dapat diterima secara signiflkan. Dengan demikian functional benefit sebagai variabel bebas berpengaruh positif terhadap attitudinal consumer loyalty. Ini berarti bahwa pada penelitian ini variabel functional benefit berpengaruh positif pada attitudinal customer loyalty sebesar $p=0,688$. Sedangkan dari hasij t-test sebagai pengujian secara parsial atau satu persatu menerangkan bahwa variabel bebas atas variabel terikatnya. Pada tabel 2 dapat dilihat tampak bahwa 
functional benefit memiliki pengaruh yang signiflkan terhadap attitudinal cutomer loyalty. Hal ini menunjukkan bahwa karakteristik suatu produk dapat memberikan pengaruh pada proses produksi secara hedonic atau proses'produk secara fungsional produk. Proses produksi secara hedonis mengutamakan pada kepusaan konsumen secara perasaan sedangkan functional attribute lebih menyampaikan pada sikap kognitif dari konsumen, sehingga semakin tepat penempatan functional benefit maka akan semakin berpengaruh terhadap konsumen dalam penggunaan produk tersebut.

Berdasarkan variabel functional benefit yang memiliki pengaruh yang signifikan terhadap attitudinal customer loyalty dengan $\mathrm{p}$ sebesar 0,688 dan $\mathrm{t}$ sebesar 8,988 (pada signifikansi $\mathrm{p}<0,05$ ). Hal ini menunjukkan bahwa penelitian ini masih sejalan dengan penelitian sebelumnya yang dilakukan oleh Anisimova (2007) yang menyatakan bahwa functional attribute memberikan nilai signifikansi terhadap pengaruh konsumen. dalam menggunakan otomotive. Hal ini diperkuat juga oleh penelitian sebelumnya yang dilakukan oleh Agarwal dan Rao dalam Anisimova (2007) dan Rio et al (2001); Sweeney dan Soutar (2001) yang menyatakan bahwa functional benefit berpengaruh positif tidak hanya kepada konsumen tetapi juga kepada pengukuran brand equity dan consumer loyalty.

\section{Hipotesis 2 :}

Ho2 : Tidak terdapat pengaruh positif antara emotional benefit terhadap attitudinal consumer loyalty

Ha2 : Terdapat pengaruh positif antara emotional benefit terhadap attitudinal consumer loyalty

Pada variabel emotional benefit yang ada dalam tabel 2 dapat dilihat bahwa. pengujian regresi linier sederhana untuk variabel emotional benefit sebagai variabel bebas dan attitudinal sebagai sebagai variabel terikat.

F-test sebagai pengujian secara keseluruhan pada persamaan regresi yang telah diuji, menunjukkan angka sebesar 45,365 dengan mempertimbangkan signifikansi dibawah $p(p=0,000$ atau $p<0.05)$, maka Ho ditolak sehingga didapat hasil bahwa persamaan regresi ini secara keseluruhan dapat diterima secara signiflkan. Ini berarti bahwa pada penelitian ini untuk emotional benefit berpengaruh positif terhadap attitudinal consumer loyalty sebesar $p=0,579$.

Sedangkan dari hasil t-test sebagai pengujian parsial atau secara satu persatu variabel bebas terhadap variabel terikatnya, pada tabel 2 tampak bahwa emotional benefit memiliki pengaruh yang signiflkan terhadap attitudinal consumer loyalty. Dengan demikian variabel emotional benefit berpengaruh pada penggunaan mobil merek Hyundai.

Variabel emotional benefit memiliki pengaruh positif yang signiflkan terhadap attitudinal consumer loyalty dengan $p$ sebesar 0,579 , dan $t$ sebesar 6,735 (signifikansi pada $\mathrm{p}<0,05$ ). Hal ini menunjukkan bahwa dengan 
penempatan emotional benefit yang tepat akan merubah kepercayaan pelanggan untuk memberikan keuntungan-keuntungan dari produk yang digunakan. Sementara penelitian yang dilakukan oleh Anisimova (2007) menyatakan juga bahwa emotional benefit berpengaruh positif pada attitudinal consumer loyally. Sehingga penelitian ini masih sejalan dengan penelitian .sebelumnya.

\section{Hipotesis 3 :}

Ho3 : Tidak terdapat pengaruh positif antara symbolic benefit terhadapa ttitudinal consumer loyalty

Ha3 : Terdapat pengaruh positif antara symbolic benefit terhadap attitudinal consumer loyalty.

Pada variabel symbolic benefit yang ada dalam tabel 2 dapat dilihat bahwa pengujian regresi linier sederhana untuk variabel symbolic benefit sebagai variabel bebas dan attitudinal consumer loyalty sebagai sebagai variabel terikat.

F-test sebagai pengujian secara keseluruhan pada persamaan regresi yang telah diuji, nenunjukkan angka sebesar 48,042 dengan mempertimbangkan signifikansi dibawah $p(p=0,000$ atau $p<0.05)$ maka Ho ditolak sehingga didapat hasil bahwa persamaan regresi ini secara keseluruhan dapat diterima secara signifikan. Ini berarti bahwa pada penelitian ini variabel symbolic benefit berpengaruh positif pada attitudinal consumer loyalt sebesar $p=0,590$.

Sedangkan clari hasil t-test sebagai pengujian parsial atau secara satii persatu variabel bebas terhadap variabel terikatnya, pada tabel diatas tampak bahwa symbolic benefit memiliki pengaruh yang signifikan terhadap altitudinal consumer loyally. Dengan demikian symbolic benefit berpengaruh secara signifikan pada attitudinal consumer loyalty pada penggunaan mobil merek Hyundai.

Hal ini menunjukkan bahwa penelitian ini masih sejalan dengan penelitian sebelumnya yang dilakukan oleh Anisimova (2007) yang menyatakan bahwa symbolic benefit memberikan nilai signiiikansi terhadap pengaruh konsumen dalam menggunakan produk otomotive.

\section{Hipotesis 4 :}

Ho4 : Tidak terdapat pengaruh positif mtsxa. functional benefit terhadap behavioral consumer loyalty

Ha4 : Terdapat pengaruh positif antSLTa functional benefit terhadap behavioral consumer loyalty

Pada variabel functional benefit yang ada dalam tabel 2 dapat dilihat bahwa pengujian regresi linier sederhana untuk variabel functional benefit sebagai variabel bebas dan attitudinal consumer loyalty,sebagai sebagai variabel terikat. 
F-test sebagai pengujian secara keseluruhan pada persamaan regresi berganda yang telah diuji, nenunjukkan angka sebesar 31,067 dengan rnempertimbangkan signifikansi dibawah $p(p=0,000$ atau $p<0.05)$ maka Ho ditolak sehingga didapat hasil bahwa persamaan regresi ini secara keseluruhan dapat diterima secara signifikan. Ini berarti bahwa pada penelitian ini variable functional benefit berpengaruh positif pada behavioral consumer loyalty sebesar $\mathrm{P}=0,507$.

Sedangkan dari hasil t-test sebagai pengujian parsial atau secara satu persatu variabel bebas terhadap variabel terikatnya, pada tabel 2 tampak bahwa functional benefit memilikk pengaruh yang signifikan terhadap behavioral consumer loyalty. Dengan demikian functional benefit berpengaruh secara signifikan pada behavioral consumer loyalty pada. penggunaan mobil merek Hyundai.

Jika dibandingkan dengan variabel functional benefit pada attitudinal consumer loyalty nilai beta pada attitudinal consumer loyalty ternyata lebih besar dari pada behavioral consumer loyalty. Hal ini menunjukkan bahwa penelitian ini masih sejalan dengan penelitian sebelumnya yang dilakukan oleh Anisimova (2007) yang menyatakan bahwa functional benefit memberikan nilai signifikansi terhadap pengaruh konsumen dalam menggunakan produk otomotive. Hal ini diperkuat dengan penelitiab yang dilakukan oleh McKinsel Marketing Sollution (2008) yang menerangkan bahwa functional benefit berpengaruh secara signifikan terhadap attitudinal consumer loyalty khususnya pada behavioral consumer loyalty.

\section{Hipotesis 5 :}

Ho5 : Tidak terdapat pengaruh positif antara emotional benefit terhadap behavioral consumer loyalty

Ha5 : Terdapat pengaruh positif antara emotional benefit terhadap behavioral consumer loyalty

Pada variabel emotional benefit yang ada dalam tabel 2 dapat dilihat bahwa pengujian regresi linier sederhana untuk variabel emotional benefit sebagai variabel bebas dan behavioral consumer loyalty sebagai sebagai variabel terikat.

F-test sebagai pengujian secara keseluruhan pada persamaan regresi berganda yang telah diuji, nenunjukkan angka sebesar 12,208 dengan mempertimbangkan signiflkansi dibawah $p(p=0,000$ atau $p<0.05)$ maka Ho ditolak sehingga didapat hasil bahwa persamaan regresi ini secara keseluruhan dapat diterima secara signiflkan. Ini berarti bahwa pada penelitian ini variable emotional benefit pun berpengaruh positif pada behavioral consumer loyalty sebesar $p=0,346$

Sedangkan dari hasil t-test sebagai pengujian parsial atau secara satu persatu yariabel bebas terhadap variabel terikatnya, pada tabel 2 s tampak bahwa emotional benefit memiliki pengaruh yang signiflkan terhadap 
behavioral consumer loyalty. Dengan demikian emotional benefit berpengaruh secara signiflkan pada behavioral consumer loyalty pada penggunaan mobil merek Hyundai.

Hal ini menunjukkan bahwa penelitian ini masih sejalan dengan penelitian sebelumnya yang dilakukan oleh Anisimova (2007) yang menyatakan bahwa functional benefit memberikan nilai signiflkansi terhadap pengaruh konsumen dalam menggunakan produk otomotive. Penelitain yang sama pun dilakukan oleh Chaudhuri dan Holbrook (2001) yang mengatakan bahwa emotional benefit berpengarh pada customer loyalty (attitudinal dan behavioral consumer loyalty).

\section{Hipotesis 6:}

Ho6 : Tidak terdapat pengaruh positif antara symbolic benefit terhadap behavioral consumer loyalty

Ha6 : Terdapat pengaruh positif antara symbolic benefit terhadap behavioral consumer loyalty

Pada variabel emotional benefit yang ada dalam tabel 2 dapat dilihat bahwa pengujian regresi linier sederhana untuk variabel emotional benefit sebagai variabel bebas dan behavioral consumer loyalty sebagai sebagai variabel terikat.

F-test sebagai pengujian secara keseluruhan pada persamaan regresi berganda yang telah diuji, menunjukkan angka sebesar 41,592 dengan mempertimbangkan signiflkansi dibawah $p(p=0,000$ atau $p<0.05)$ maka Ho ditolak sehingga didapat hasil bahwa persamaan regresi ini secara keseluruhan dapat diterima secara signifikan. Ini berarti bahwa pada penelitian ini variable symbolic benefit berpengaruh positif pada behavioral consumer loyalty sebesar $p=0,562$.

Sedangkan dari hasil t-test sebagai pengujian parsial atau secara satu persatu variabel bebas terhadap variabel terikatnya, pada tabel 2 tampak bahwa emotional benefit memiliki pengaruh yang signiflkan terhadap behavioral consumer loyalty. Dengan demikian emotional benefit berpengaruh secara signiflkan pada behavioral consumer loyalty pada penggunaan mobil merek Hyundai. Berdasarkan analisis di atas bahwa pengujian pada hipotesis tersebut dari penelitian ini masih sejalan dengan penelitian yang dilakukan oleh Anisimova (2007) yang menyatakan bahwa symbolic benefit berpengaruh positif pada behavioral consumer loyalty. Hal ini sejalan dengan penelitian yang dilakukan saat ini.

\section{G. Kesimpulan}

Kesimpulan yang dapat diambil antara lain bahwa variabel functional benefit pada pelanggan jasa service mobil merek Hyundai memberikan pengaruh yang signifikari terhadap attitudinal customer loyalty maupun behavioral consumer loyalty yang artinya bahwa responden merasa loyal dan 
merasakan kepuasan terhadap layanan yang diberikan oleh showroom Pondok Indah - Jakarta Selatan.

Begitu juga dengan emotional benefit, pelanggan mendapatkan keuntungan emosional dengan menggunakan showroom Pondok Indah sehingga variabel emotional benefit berpengaruh secara signifikan terhadap attitudinal consumer loyalty maupun behavioral consumer loyalty. Dalam hal ini menandakan ikatan emosional pengguna mobil merek Hyundai cukup tinggi sehingga memberikan loyalitas pada pelanggannya.

Sedangkan pengaruh symbolic benefit juga mempunyai pengaruh terhadap attitudinal dan behavioral customer loyalty. Hal ini menandakan bahwa dengan menggunakan symbolic benefit yang baik pengguna mobil merek Hyundai akan lebih loyal menggunakan pelayanaan yang diberikan oleh showroom Pondok Indah - Jakarata Selatan. Sehingga responden pun bersedia untuk dapat merekomendasikannya kepada khalayak luas akan pelayanan yang diberikan oleh showroom Pondok Indah - Jakarta Selatan, hal ini merupakan salah satu bentuk loyalitas konsumen kepada produk yang dipakainya.

Dari hasil penelitian dan pengolahan data yang sudah dilakukan, dapat ditarik kesimpulan dari masing-masing hipotesis antara lain : Pertama, terdapat pengaruh yang positif antara functional benefit terhadap attitudinal consumer loyalty. Hal ini menandakan bahwa semakin baik penempatan functional benefit maka akan semakian loyal pengguna menggunakan mobl merek' Hyundai untuk kegiatan pribadinya. Kedua, terdapat pengaruh yang positif emotional benefit terhadap attitudinal consumer loyalty, hal ini menunjukkan bahwa pengguna mobil merek Hyundai mendapatkan keuntungan -keuntungan yang bersifat afektif dan kognitif yang diberikan oleh pelayanan showroom Pondok Indah - Jakarta Selatan, sehingga pengguna mobil merek Hyundai loyal terhadap pelayanan mobil merek Hyundai terutama pada showroom mobil merek Hyundai Pondok Indah Jakarta Selatan.

Kesimpulan ketiga dari hipotesis ini adalah bahwa terdapat pengaruh yang positif antara symbolic benefit terhadap attitudinal consumer loyalty. Hal ini menunjukan bahwa bahwa keuntungan-keuntungan yang didapat dari luar terhadap produk atau ja'sa yang dilayankan memberikan loyalitas bagi pengguna mobil merek Hyundai terutama pada pelayanan yang diberikan oleh showroom mobil merek Hyundai Pondok Indah - Jakarta Selatan.

Keempat terdapat pengaruh yang signiflkan antara functional benefit terhadap behavioral consumer loyalty, hal ini menunjukkan bahwa keuntungan-keuntungan yang diperoleh dari pengguna mobil merek Hyundai dengan menggunakan pelayanan yang diberikan di showroom Pondok Indah - Jakarta Selatan memberikan dampak kesetiaan perilaku konsumen pada showroom mobil merek Hyundai di showroom Pondok Indah Jakarta Selatan. 
Sehingga secara tidak langsung pengguna mobil merek Hyundai datang dan berkunjung kembali ke showroom tersebut untuk memanfaatkan pelayanan yang diberikan showroom tersebut, dan secara tidak langsung pengguna rnobil merek Hyundai memberikan rekomendasi pada temen-teman, kerabat dan orang-orang disekitarnya.

Kelima, terdapat pengaruh yang signiflkan pada emotional benefit terhadap behavioral consumer loyalty. Hal ini berarti bahwa pengguna mobil merek Hyundai dengan menggunakan pelayanan yang diberikan oleh showroom Hyundai Pondok Indah - Jakarta Selatan memberikan dampak kesetiaan perilaku konsumen dalam menggunakan pelayanan yang diberikan oleh Showroom Mobil Merek Hyundai di showroom Pondok Indah - Jakarta Selatan.

Keenam, kesimpulan yang dapat diambil adalah terdapat pengaruh yang signifikan symbolic benefit terhadap behavioral customer loyalty, hal ini menandakan adanya keuntungan yang berasal dari luar terhadap produk atau jasa yang diberikan sehingga mempengaruhi atau memberikan dampak kesetiaan secara prilaku terhadap penggunanya. Dalam hal ini adalah bahwa pengguna mobil merek Hyundai mendapatkan keuntungan yang berdampak pada loyalitas secara perilaku yang disiratkan melalui penggunaan kembali layanan atau produk yang ada di showroom Pondok Indah - Jakarta Selatan serta merekomendasikannya kepada lingkungan sekitarnya.

\section{H. Daftar Pustaka}

An-Tien Hsieh dan Chung-Kai Li, (2008), "The Moderating Effect of Brand Image on Public Relations Perception and Customer Loyalty", Marketing Intelligence \& Planning, Vol26No.I

Anisimova, Tatiana Anatolevena, (2007), "The Effects of Corporate Brand Attributes on Attitudinal and Behavioural Consumer Loyalty", Journal of Consumer Marketing, Vol 24/7

Bloemer, Josee; Ko de Ruyter dan Martin Wetzels. (1999), "IMLinking perceived service quality and service loyalty: a multi-dimensional perspective",. European - Journal of Marketing. Vol. 33. Iss. 11/12

Bennet, Rebekah dan Sharyn Rundle-Thiele, (2000) "Attitudinal Loyalty Personality trait or brand specific?", ANZMAC 2000 Visionary Marketing for the 21st Century: Facing the Challenge

Brucks, M., Zeithaml, V.A. and Naylor, G. (2000), "Price and brand name as indicators of quality dimensions for consumer durables", Journal of Academy of Marketing Science, Vol. 28 No. 3

Da Silva, Rui Vinhas, "Online Brand Attributes and Online Corporate Brand Images", Manchester Business School (West)- University of Manchester 
Dacin, P.A. and Brown, TJ. (2006), "Corporate branding, identity, and consumer response", Journal of the Academy of Marketing Science, Vol. 34, Spring

Fajrianthi dan Zatul Farrah, (2005), "Strategi Perluasan Merek dan Loyalitas Konsumen", Insan, Vol 7 No,3

Hart, Allison E, dan Philip J Rosenberger III, (2004), "The Effect of Corporate Image in the Formation of Customer Loyalty: An Australia..."? Australasian Marketing Journal; 2004; 12,3

IBIS World (2005), "Motor Vehicle Manufacturing in Australia, C2811 Series", IBISWorld, Melbourne, August.

Indrakusuma, Johanes dan Lena Ellitan, (2008), "Analisis Multi Atribut yang Mempengaruhi Preferensi Belanja Online Produk Tiket Pesawat di Kalangan Mahasiswa UKWSMS, National Conference UKWNS, Surabaya, 6 September

Ja-Shen Chen dan Russell K.H. Ching, (2007), "The Effects of Mobile Customer Relationship Management on Customer Loyalty: Brand Image Does Matter", System Sciences, 2007. HICSS 2007. 40th Annual Hawaii International Conference

Kaynak, Erdener; Gulberk Gultekin Salman dan Ekrem Tatoglu, (2007), "An Integrative Framework Linking Brand Associations and Brand Loyalty in Professional Sport", Brand Management, Vol 15 No 5

Knox, S. and Bickerton, D. (2003), "The Six Conventions of Corporate Branding", European Journal of Marketing, Vol. 37 Nos 7/8,

Kotler dan Amstrong, (2008), "Principles of Marketing", Prentice Hall, New Jersey Lloyd, S. (2004), "The-driving force", BR W, July 1-7,

Martenson,. Rita, (2008), "How financial advisors affect behavioral loyalty", InternationalJournal ofBankMarketing, Vol 26 No.2

Musa, Rosidah (2005), " A Proposed Conceptual Framework Of Satisfaction-Attitudinal Loyalty-Behavioural Loyalty Chain : Exploring The Moderating Effect Of Trust", ANZMAC 2005 Conference: Relationship Marketing...

Merrilees, B. and Fry, M-L. (2002), "Corporate branding: a framework for eretailers", Corporate Reputation Review, Vol. 5 Nos 2/3

Putri, Rinella (2007), "menciptakan loyalitas elanggan melalui emotional benefit", Vibiznews.com, Oktober 2007

Schultz, M. and de Chernatony, L. (2002), "The challenges of corporate branding", Corporate Reputation Review, Vol. 5 Nos 2/3

Sirohi, Niren; Edward W. McLaughlim dan Dick R. Wittink, (1998), "A model of Consumer Perception and Store Loyalty Intention for Supermarket...", Journal of Retailing, Summer; 74

Subroto, Asto, (2007),' "Corporate Brand,penggerak utama komitmen konsumen?", www.astrosubroto.com 
Sweeney, J.C. and Sotitar, G.N. (2001), "Consumer perceived value: the development of a multiple item scale", Journal of Retailing, Vol. 77, pp. 203-20.

Tickle, P., Keller, L.K. and Richey, K. (2003), "Ten guidelines for branding in high-tech markets", The Journal of Marketing Society, Vol. 22, Autumn 